\title{
Marginal and average prices of land lots should not be equal: A critique of Glaeser and Gyourko's method for identifying residential price effects of town planning regulations
}

\author{
Cameron K. Murray*
}

November 25, 2019

\begin{abstract}
Glaeser and Gyourko's (2003) (henceforth G\&G's) method of measuring the gap between marginal and average land prices of housing lots has become a popular way of demonstrating the degree to which planning controls, or "regulatory taxes", increase residential land prices. This has led policy-makers across the globe to focus on town planning as a critical determinant of rising home prices. We show, however, that G\&G's method shows no such thing. Instead, the price gap is a product of the location premium of land, diminishing returns to buyers of residential land size, and historical city development patterns.

Numerous shortcomings are identified in their theoretical model, including that (1) they ignore that development happens over time, (2) their "regulatory tax" is simply the location value of land, (3) they reason inconsistency about the source of land prices, arguing that land at the margins is scarce but locations for a whole housing lots are not, and (4) there are no optimal lot sizes nor subdivision incentives in their model. Standard price-taking models of residential land markets that recognise that locations are scarce contain none of these limitations and provide a better interpretation of land price patterns.

Empirically, we show that G\&G's method finds a high "regulatory tax" even in the absence of regulatory constraints using both simulated suburb development scenarios and historical land sales data from colonial Australia and ancient Mesopotamia. In short, there is no information regarding the effect of planning controls on the supply of new dwellings in a comparison of marginal and average land prices and this method should not be relied upon to inform planning and housing policy decisions.
\end{abstract}

Keywords: Land value; Marginal land price; Zoning; Planning; Supply. JEL Classification: R21, R28, R31, R52.

\footnotetext{
*Henry Halloran Trust, The University of Sydney, Camperdown NSW 2006. Email: ckmurray@gmail.com This project was funded by the Henry Halloran Trust. https://sydney.edu.au/henry-halloran-trust/ Thanks to Tim Helm and Peter Phibbs for their constructive comments on early drafts.
} 


\section{Introduction}

Glaeser and Gyourko's (2003) (henceforth G\&G's) method for identifying the housing price effect of town planning regulations has become influential in shaping housing policy. Policy think-tanks and government agencies in many areas that had housing price booms from 2012 to 2018 have targeted town planning rules to tackle rising prices based on analysis using G\&G's method, such as in New Zealand (Lees, 2018), Australia (Kendall \& Tulip, 2018), and California (Sunding \& Swoboda, 2009). ${ }^{1}$ However, G\&G's method does not measure what it is claimed to measure.

G\&G's method is simple. They assume that the sale price of a detached house with $L$ units of land, $P(L)$, is $K+T+p L$, where $K$ is the construction cost of the house, $T$ represents zoning, building restrictions, or taxes on new construction, and $p$ is the "free-market price" of land (Glaeser \& Gyourko, 2003, p.28). In an equilibrium, $P(L)$ must equal $K+T+p L$ and $P^{\prime}(L)$ must equal $p$. They wish to estimate $T$ in their model. Since they observe $P(L)$ and $K$ but not $p$ and $T$ in their detached owner-occupied housing data, they first subtract construction costs from home prices (computing $P(L)-K$ ) to give an estimate of $T+p L$. Using standard hedonic analysis to estimate $P^{\prime}(L)$ (i.e. $p$ in their model), they can then reverse out their estimate of $T$, the "regulatory tax" per housing lot. This tax is the difference between the average price of land and the estimated marginal price of land for a housing lot. G\&G note that what they call a "regulatory tax" could alternatively be the result of zoning or minimum lots sizes that act as binding supply constraints as "a tax and a quantity limit will yield the same outcomes" (Glaeser \& Gyourko, 2003, p.28).

G\&G infer that if the marginal price of land is lower than the average price there is an arbitrage opportunity to assemble pieces of land at the marginal price into new lots and sell them at the higher average price per square metre. If this does not happen, regulations are likely to be constraining this arbitrage opportunity. The difference between the lot value and the value as if all the land was available at the marginal price is called a "regulatory tax", which is claimed to reflect a price outcome of either (1) taxes on new housing construction such as impact fees or developer charges, (2) limits on the total quantity of housing in a city that increase average prices, (3) minimum lot size controls that restrict the arbitrage opportunities towards optimal land sizes, or (4) some combination of these constraints. There is ambiguity about what precisely this "regulatory tax" means in practice for a landowner, and we later consider multiple plausible interpretations. Regardless, it appears to represent the sub-optimality of lot size across the city (i.e. lot sizes are larger than some optimum), and hence can be interpreted as an indicator of constraints on land subdivision.

G\&G found extremely high estimates for their "regulatory tax" in U.S cities, for example accounting for $91 \%$ of the total land price for a detached housing lot in Los Angeles and Detroit, and $76 \%$ in Philadelphia (Glaeser \& Gyourko, 2003, p.30). Later studies using G\&G's method have also found large "regulatory tax" components of land price, such as Kendall and Tulip's (2018) 74\% estimate for Sydney, Australia, and Lee's (2018) 89\% estimate for Auckland, New Zealand.

Despite the significant and increasing policy influence of G\&G's method, only minor critiques have previously been made. O'Flaherty's (2003) comment on G\&G's paper when it was first published in the conference issue of the Federal Reserve Bank of New York Policy Review is the

\footnotetext{
${ }^{1}$ Their theory and method also forms the conceptual foundations of later influential work (Glaeser et al. , 2005). The results from these methods have become a foundation for urban policy debates about planning regulations and housing prices amongst policy think-tanks and major institutions (such as Girouard et al. (2006), Niemietz (2012), Hilber \& Vermeulen (2015) and MacDonald (2016)).
} 
most pointed of the two existing critiques. In regard to G\&G's interpretation of the gap between average and marginal land prices of housing lots as being due to regulatory constraints, he made three important points.

1. Land is not a quantity. People are not indifferent between a parcel of land of 500 square metres and 500 one square metre parcels of land in different locations.

2. Housing lots come in 'lumps' and hence subdivision represents a 'suitcase problem' of choosing a fixed number of lots and their sizes to fit in the plot being subdivided. ${ }^{2}$ Even a new subdivision will therefore not always be able to have housing lots of the exact size where marginal and average land prices are equal.

3. Even if new housing lots are created optimally when subdivided, they won't stay that way for long as demand changes over time at each location. A continuous and complete rebuilding of the city is required to maintain optimally-sized lots.

O'Flaherty (2003) concludes that "the equality of marginal and average cost of land upon which the Glaeser and Gyourko paper is based will not be observed very often in neighbourhoods more than a few years old, even in the best of all possible cases". One defence against this critique is that even though it is strictly true, discovering the relative degree to which cities are able to move closer to a point where marginal and average lot prices are equal might still be a merit of G\&G's method.

Somerville (2005) raised similar concerns, also noting that G\&G's method requires that town planning regulations do not generate "any benefits that manifest themselves in a higher land price" (Somerville, 2005, p. 28). If town planning regulations do create economic benefits in terms of higher location values for land, then G\&G are measuring the economic benefits of planning controls while calling them costs. Indeed G\&G try to have it both ways when they implicitly identify higher land prices as benefits by noting that the "positive impact of zoning on housing prices may well be zoning's strongest appeal" (Glaeser \& Gyourko, 2003, p.35).

Both critiques acknowledge that planning controls can increase land prices but do not believe that this is what G\&G's method demonstrates. Unfortunately, these critiques are relatively unknown, as the citation counts shows; there are over 750 citations for G\&G's paper ${ }^{3}$ but just two for O'Flaherty's (2003) comment and five for Somerville's (2005) critique, according to Google Scholar (as at 12 November 2018).

Given renewed policy interest during recent home price booms in many cities globally, the fact that these sensible critiques have been ignored warrants this more substantial one. We undertake this new expanded critique as follows. First, we identify numerous shortcomings in the theory G\&G rely on to interpret the difference between marginal and average land prices as being due to "regulatory taxes" (Section 2). These include the fact that (1) city development takes place over time and lots cannot be continuously remade to the optimal size, that (2) the "regulatory tax" is merely the location value, that (3) their theory is inconsistent about the source of land values, and that (4) their theory contains no incentive for subdivision because there are no optimal lot sizes. We then show that an alternative theory, where land is scarce, location premiums exist,

\footnotetext{
${ }^{2}$ Briefly, the suitcase problem is packing problem in which the objective is to fit as many items of a fixed size and shape in a container of set dimensions. Any block of land of a certain size and shape is highly unlikely to be able to be subdivided in such a way that all the new subdivided lots are the optimal size (where average and marginal land price are equal). The only way this can happen is if the lot being subdivided is an integer multiple of the optimally-sized lot after taking into consideration street design, access, and geographic constraints.

${ }^{3}$ There are 426 citations of their 2003 paper, 245 for the NBER working paper version, and 87 citations of a 2002 version published in the Regulation journal under the title 'Zoning's steep price' (Glaeser \& Gyourko, 2002).
} 
and the average utility (bid-rent) curve is an inverted-U shape, explains the gap between average and marginal prices, but contains none of these other limitations.

Second, we demonstrate that the G\&G method will find high "regulatory taxes" even in unconstrained land markets by applying their method to a simulated suburb where development occurs with a known data-generating process (Section 3). G\&G's method is applied to four development scenarios to show that it cannot identify constraints on total supply, nor the effect of minimum lot size controls.

Lastly, rather than a hypothetical, the G\&G method is applied to two historical cases where town planning constraints like minimum lot sizes and building permits are highly unlikely to be a factor determining the pattern of marginal and average land prices (Section 4). These cases are colonial Australia in the 1850s and ancient Mesopotamia in the third millennium B.C.. In both cases, the method finds large "regulatory taxes" of around $46 \%$ of land prices in colonial Australia, and 16-34\% of land prices in ancient Mesopotamia, demonstrating that the location values that G\&G identify as a "regulatory tax" are a timeless feature of land markets.

Given that there is likely to be large economic benefits from effective and efficient housing and planning policies, it is important to develop a clear understanding of what planning can and cannot achieve in terms of land price effects. To improve that intellectual effort we must move on from the flawed analysis of the G\&G method.

\section{Theoretical critiques}

\subsection{Problems in G\&G's theory and method}

Major problems with G\&G's method involve the theoretical assumptions they rely upon to interpret the gap between marginal and average land prices of a housing lot as being due to taxes on new housing or restrictions on land subdivision. They note that their theory is fundamentally different from classical theories of land prices, and offer their method as evidence that differentiates between these two competing theories and supports their own.

First, there is the classic economics approach, which argues that houses are expensive because land is expensive. According to this view, there is a great deal of demand for certain areas, and land, by its very nature, is limited in supply.

Our alternative view is that homes are expensive in high-cost areas primarily because of government regulation, that is, zoning and other restrictions on building. According to this view, housing is expensive because of artificial limits on construction created by the regulation of new housing. It argues that there is plenty of land in high-cost areas, and in principle new construction might be able to push the cost of houses down to physical construction costs. (Glaeser \& Gyourko, 2003, pp.22-23)

However, a gap between average and marginal land prices for housing lots is also consistent with the classical theory they seek to discredit, as we will see in Section 2.2. If the data cannot differentiate the theories, then the validity of their theory rests upon the reasonableness of its assumptions, its internal consistency, and its capacity to predict other key housing supply behaviours. This Section shows that many of G\&G's key theoretical assumptions are unreasonable and inconsistent. 


\subsubsection{The neglect of timing issues}

Land development takes place over time. As O'Flaherty (2003) noted, even if land is optimally subdivided at the time the subdivision occurs, these lots will soon be non-optimal as soon as any market parameters, such as demand, change. G\&G, however, assume a mechanical relationship between planning controls that limit the number of housing lots per area, such as minimum lot sizes, and the amount total stock of housing across a city. They explain that "[i]n principle, zoning could also work by limiting the total number of homes in the area to a fixed number or, equivalently, by constraining lot size to be greater than a given amount" (Glaeser \& Gyourko, 2003, p.28). This is equivalent to assuming that all future development opportunities across the whole city have already been undertaken, and indeed, the whole city is redeveloped instantly when patterns of demand for housing change. While they might argue that their static model is a good interpretation of the outcomes of a long-run process, there are two problems with this assumption that undermine their method.

First, if all residential lots are remade instantly to the optimal size as assumed, there can be no lot size variation at any location. Without any lot size variation the marginal land value cannot be measured. This is also true in the case where minimum lot size controls bind all lots to be the same larger-than-optimal size at all points in time. In short, G\&G's method cannot produce an estimate of marginal land prices if the data generating process is as their theory assumes, whether in a constrained or unconstrained land market, as both result in identically sized lots at each location. The existence of the lot size variation necessary to generate empirical estimates of marginal land price must come from the fact that land is subdivided under different economic and geographic constraints at different points in time.

Second, constraints on lot density, like minimum lot sizes, are not constraints on the rate at which new lots can be created and sold, which is what cumulatively determines total housing supply. If all potential new supply has not been developed, then the rate of supply is mostly determined by the timing decisions of potential land developers who face an optimisation problem with two control variables - the time they strike their development option, and the density at which they develop at that time. While there may be a quite complex relationship between timing decisions and allowable development density, it is not necessarily the case that these are positively related (i.e. more dense subdivisions are not necessarily sold, or produced, faster). ${ }^{4}$ Indeed, planning controls can accelerate the pace of development if they reduce the landowners payoff from delaying (Titman, 1985). The assumption that lot size controls restrict total housing supply overlooks important timing issues.

\subsubsection{The "regulatory tax" is the location value}

In G\&G's theory their measured "regulatory tax" is the location value of land. As they note, their "zoning view suggests that higher amenities will just lead to a higher implicit zoning tax." (Glaeser \& Gyourko, 2003, p.31). Is it reasonable that there can be no location premium for land except due to regulatory constraints?

We can see how the "regulatory tax" is the location value by looking at both the supply and

\footnotetext{
${ }^{4}$ It has been known since Shoup (1970), and later Markusen \& Scheffman (1978), that land subdivision to higher density uses will mainly depend on the rate of change in the value of the stock of land held and the discount rate (or opportunity cost) of the developer. As reiterated in Murray (2018), if the value of land held is rising faster than the discount rate, the incentive is to delay the rate new land development, and vice-versa when the value change is less than the discount rate.
} 
(a)

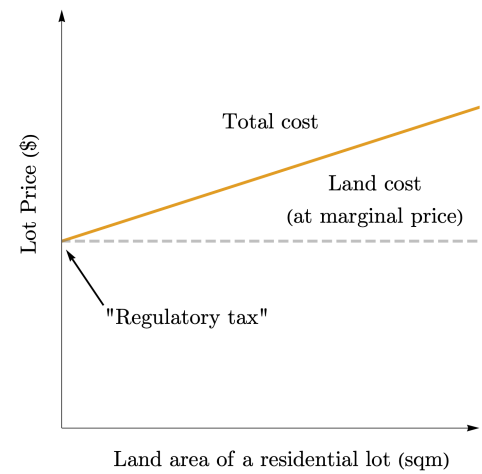

(b)

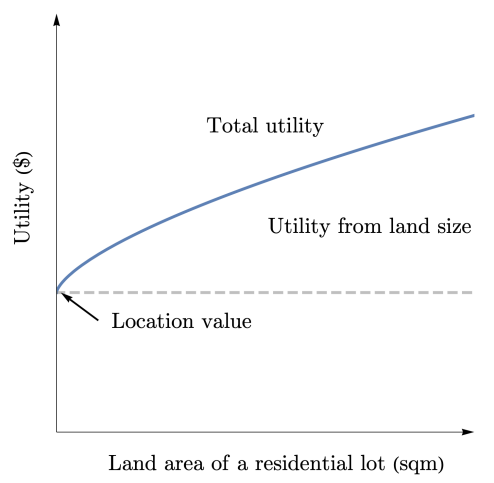

(c)

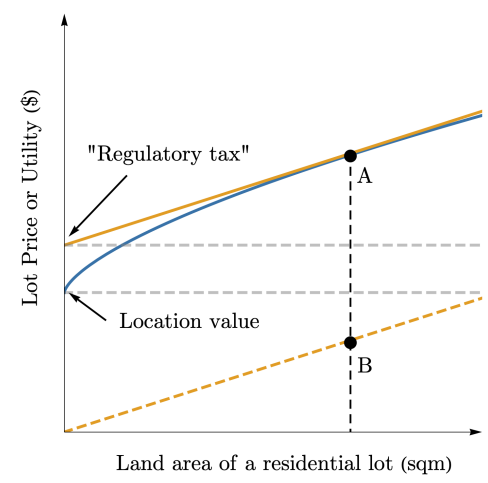

Figure 1: Total utility and cost alongside demand and supply as described in the G\&G model

demand side of the land-per-lot market in their model. On the supply side, the total cost function with respect to land area per lot is $T+p L$ (shown in Panel (a) of Figure 1). On the demand side, their total utility (bid-rent) of land for a detached home includes a lump sum utility value of location, $l o c$, and a concave (or diminishing) utility value in terms of land size, or $l o c+V(L)$, where $V(L)=L^{\alpha}$ and $0<\alpha<1$. Panel (b) of Figure 1 shows a representation of such a total utility (bid-rent) curve. Note that higher location values will shift the total utility curve up without having any effect on the marginal value of additional land per lot, just as an increase in $T$ on the supply side increases the total cost per lot but does not change the marginal cost.

Panel (c) of Figure 1 puts together total cost and total utility curves based on G\&G's model, with the marked Point A being the equilibrium point where marginal utility equals marginal prices, and total utility equals total price. Notice that in their assumed equilibrium the "regulatory tax" is merely the lump sum location value plus the diminishing returns to land that occur before Point A. If land price data is scattered around Point A, its slope will reflect both the marginal utility and marginal cost curves at that point. G\&G merely assume the distribution of data around Point A is caused by the cost (supply) side of the market.

Their reasoning is that highly competitive land selling and land redevelopment at every location will reduce land prices to input costs. If the "regulatory tax" was removed, as shown by the dashed orange total cost curve in Panel (c) of Figure 1, G\&G argue that the unlimited variety of housing options at every location at this lower cost would provide an array of substitute lots for land users who will reduce their total utility (bid-rent) curve downwards to this new lower cost curve, eliminating any location premium. Hence, the cost curve determines the utility (bid-rent) curve.

The alternative view, which is more reasonable and consistent, is that location values exist even in the absence of "regulatory taxes". All that needs to be assumed is that land prices are set by price-taking due to competition on the demand side for locations that are inherently scarce. This includes competition for use by the current landowners (i.e. potential sellers) who are also part of the representative consumer and have the same utility (bid-rent) function from owning land and will not sell below this value. In this case, there is no need to assume a cost structure in land markets - the total price of land in a housing lot will merely reflect total utility, the marginal price will reflect marginal utility, and observed prices will contain no information about the input costs of supply. 


\subsubsection{Inconsistency about the source of land values}

That the measured "regulatory tax" is determined by location values that cannot be eliminated due to supply-side competition is also relevant to an important inconsistency in G\&G's theory about the source of marginal land prices. They reason that there is a positive marginal "free market" cost of land (i.e. $p>0$ ), but have no explanation of where this price comes from. If there is an effectively infinite supply of new lots at all locations that can bring down land prices to input costs, as they assume, then the margins of lots are also in infinite supply at all locations. Competitive selling of these marginal areas will also bring their price down to their input cost of zero. In fact this is what they argue when introducing their theory as an alternative to one in which land is scarce. ${ }^{5}$

According to this view, housing is expensive because of artificial limits on construction created by the regulation of new housing. It argues that there is plenty of land in high-cost areas, and in principle new construction might be able to push the cost of houses down to physical construction costs" (Glaeser \& Gyourko, 2003, p.23)

Later authors have recognised that "the marginal valuation represents the opportunity cost" of land which could be attached to a different lot instead (Kendall \& Tulip, 2018, p.10). Yet the value of the total lot also represents an opportunity cost of use by the current owner. Thus, both average and marginal land costs represent the opportunity cost of use at that location (i.e. all land prices are determined by demand).

In fact, in later work, G\&G argue that it is the total price of a housing lot which is determined by regulatory constraints (Glaeser et al. , 2005). When they look at vertical rather than horizontal space, they argue that a positive value of a 'vertical space lot', where the price of a housing apartment is above its construction cost, indicates a restriction on apartment supply. In this case their model is "regulatory tax = market price of a housing unit - marginal cost of that unit (absent government barriers)", where "the marginal cost of a new housing unit is reflected in the cost of building up" (Glaeser et al. , 2005, p.336). In the notation used here, the model is $P=K+T$, where land (space) size and marginal land (space) price does not enter the model. In this case, they simply assume that both the average price of space per lot and the marginal "free market price" of space (i.e. land) per lot should be zero in the absence of "regulatory taxes".

\subsubsection{Subdivision is non-economic and there is no optimal lot size}

Since land for new housing comes from subdividing larger lots, G\&G's own theory provides no incentive for subdivision, and hence cannot identify optimal lot sizes (i.e. lot sizes that maximise total land value). If $T$ is a tax paid per subdivided lot, then a landowner only earns the lot price net of the tax on subdivided lots as if $T=0$. Their revenue per square metre is simply $p$ regardless of how many lots they subdivide into. Landowners are therefore always indifferent to subdivision and there is never an incentive to subdivide - all lot sizes have the same value per square metre.

The other interpretation of the economic incidence of $T$ that G\&G put forward is that it is the equilibrium price effect of a quantity control and landowners receive this gain. If this is the

\footnotetext{
${ }^{5}$ In a comment on the state of economics at the time, Leon Walras in 1896 wrote that those with accurate economic theories of property received little attention, whereas "In contrast, somebody who succeeds in making himself and other people believe that land sold at 1,000, 1,500 or even 2,000 francs per square metre has no value, will achieve everything" (Walras, 2010, p.245). This situation is once again being repeated following the renaissance of such ideas in G\&G's influential work which explicitly states that
} 
case, the landowner gets $T+p L$ as their revenue for each lot. Here, the optimal subdivision lot size converges to zero (since their return per lot area $R(L)=(T+p L) / L$ and is maximised with respect to $L$ when $L=0$ ). Neither interpretation of the G\&G supply side assumptions can help determine optimal lot sizes, nor do they provide any incentives for subdivision and new lot supply, the very process it seeks to describe. ${ }^{6}$

\subsubsection{Other notable issues}

Tax incidence matters: G\&G state that they "are not interested in the incidence of the policy, a tax and a quantity limit will yield the same outcomes" (Glaeser \& Gyourko, 2003, p.31). But the incidence of a tax on new land supply for housing is crucial for determining potential price effects. They simply assume the incidence of a tax in a new housing development is on the land buyer (or user), and therefore it is equivalent to a fixed supply limit. Figure 2 shows this assumed tax incidence in Panel (a) and the equivalent supply constraint in Panel (b). But if prices are set by total utility (bid-rent) rather than cost, as in the standard case of a vertical supply curve, then such a tax is fully incident on the landowner, as in Panel (c) of Figure 2. In this case, there is no price effect and the tax is incident on the landowner's economic rent. This is the way land appraisers (or valuers) view such taxes and is a view that is empirically supported (Murray, 2018). Therefore their assumptions about tax incidence seem unwarranted.

(a)

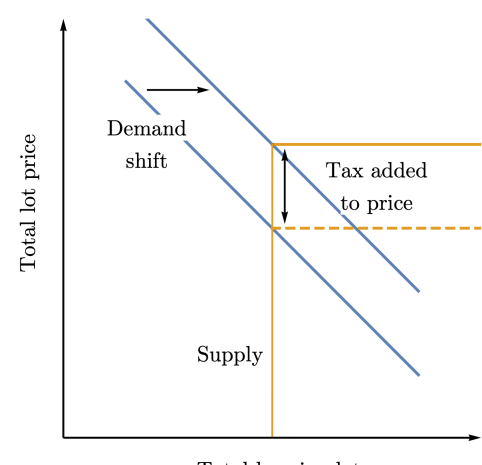

Total housing lots (b)

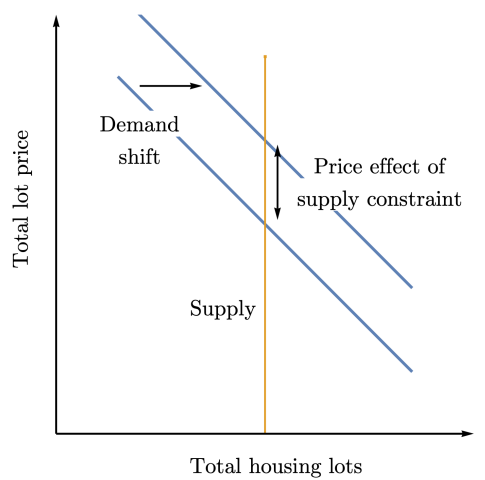

(c)

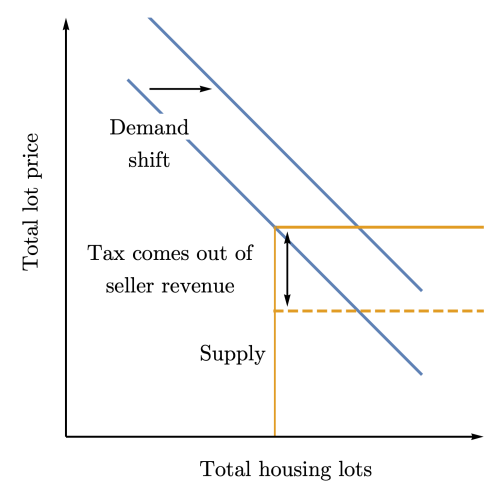

Figure 2: On tax incidence on the buyer coincides with supply constraints

Inconsistent land and lot supply reasoning: G\&G reason inconsistently by describing a model of demand and supply of the total number of lots in a city without any reference to whether a city is above or below some "free-market" benchmark number of homes, nor whether a city with an 'excess' total number of homes cannot exhibit the same marginal and average land price patterns. It is possible that marginal land prices can be far below average in a city with perfectly elastic new supply and/or falling prices, as long as there is a location premium for some land and a variation in lot size based on historical subdivision patterns that allow the marginal value of land to be estimated. The fact that Detroit and San Francisco both produced estimates of extremely high "regulatory taxes" is further evidence that the average and marginal prices do

\footnotetext{
${ }^{6}$ One could also interpret $T$ to be potentially levied on a per square metre basis, giving a lot supply price of $T(L)+P(L)$. But this undermines the whole logic of the gap between marginal and average prices reflecting a tax on new housing, as marginal price would be $P^{\prime}(L)+T^{\prime}(L)$, where $T^{\prime}(L)$ is the per square metre tax.
} 
not contain information about the overall rate of new housing supply, and therefore the housing stock, across a city.

Minimum lot sizes can reduce the "regulatory tax": G\&G assume that minimum lot sizes constrain total lots in a city, increasing the whole city's location value thus creating a positive $T$, but ignore that larger lots at a location (i.e where the location value is fixed) will have a smaller gap between marginal and average price under their assumptions on supply. For example, if the location value (or "regulatory tax") of an area is $\$ 100$ and the marginal price is $\$ 5$ per square metre (and $\alpha=1$ ), then a plot of 500 square metres will have an average price of $\$ 5.2 / \mathrm{sqm}$ and a lot of 1,000 square metres will have a lower average price of $\$ 5.1 / \mathrm{sqm}$, while they both have the same $\$ 5 / \mathrm{sqm}$ marginal price. Even if minimum lots sizes increase location values, the effect of larger lots in the data at this location value will be to reduce the estimate of the "regulatory tax" according to the logic of G\&G's model.

\subsection{Benefits of an Inverted-U price-taking theory}

One way to show the limitations of G\&G's theory is to compare it to the classical alternative theory they seek to discredit in terms of the reasonableness of their assumptions, their internal consistency, and their capacity to predict other key housing supply behaviour.

The alternative theory is that landowners are price-takers from competition between themselves and potential buyers for exclusive use of scarce locations where the willingness to pay for these locations - the utility (bid-rent) curve - depends on the relative attractiveness of alternative locations. In this theory, a land user's total utility (bid-rent) curve depends positively on both locational attributes and lot size. With respect to lot size the total utility (bid-rent) curve begins at zero and has a convex portion up to a certain useful size, then concavity above that size (at each location) towards a fixed asymptote. This creates an inverted-U-shaped average (and marginal) utility curve, as shown in Figure $3,{ }^{7}$ which has the following features:

- There is a range of impractically small lot sizes for residential uses where increasing land size has increasing returns to scale.

- There is an optimal subdivision size at a location at the peak of the average value curve.

- Above-optimal lot sizes have lower marginal compared to average values.

- Marginal values are always positive (i.e. bigger lots are always worth more than smaller ones) but fall with lot size.

This Inverted-U model ${ }^{8}$ is based on fewer, and more reasonable, assumptions than G\&G's model, is internally consistent, and resolves the previously identified shortcomings.

1. There are no assumptions about total housing supply and equilibrium (such as that all lots are already maximally developed). Lots subdivided at different historical periods will exist.

2. A higher average compared to marginal price for housing lots indicates more than location value, specifically that lots are sub-optimally large based on current utility (bid-rent) curves.

\footnotetext{
${ }^{7}$ The functional form used here is described in Equation 1.

${ }^{8}$ Refer to Table A1 of the Appendix for a comparison of key theoretical features of the Inverted-U and G\&G models
} 
(a)

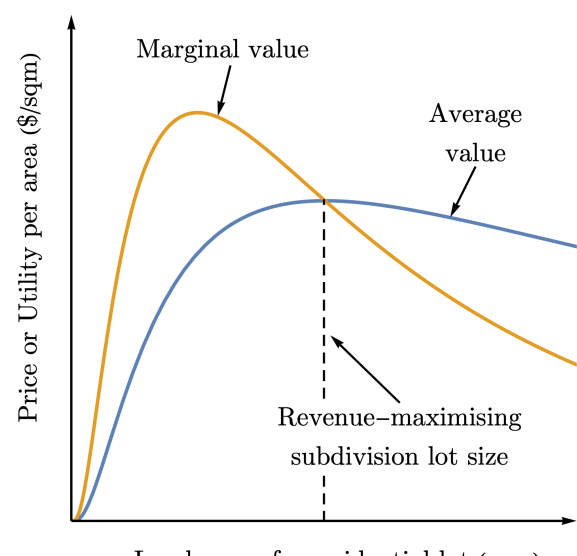

Land area of a residential lot (sqm) (b)

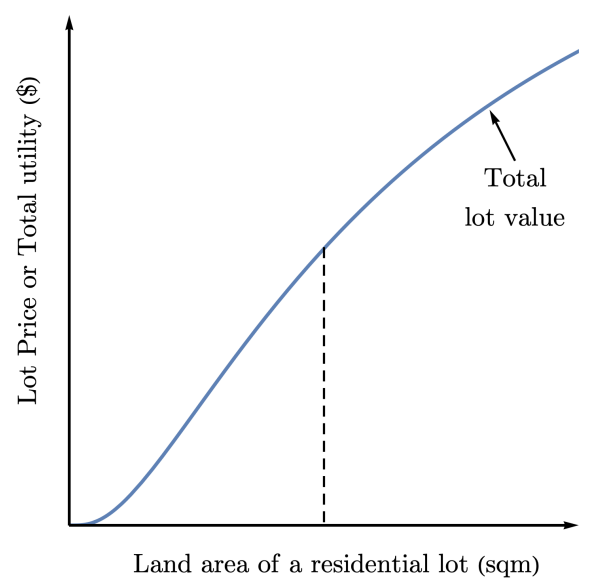

Figure 3: Inverted-U model average, marginal (Panel (a)), and lot value (Panel (b)) curves

3. It is consistent about the of source of land values. Both marginal and average values are determined by the shape of the utility (bid-rent) curve at that location.

4. There is an incentive to subdivide into smaller lots, and an optimal lot size for a subdivision. A lot can be profitably subdivided if the value of $x$ smaller lots of at $1 / x$ the size exceeds the value of the existing lot, or $x\left(P\left(\frac{L}{x}\right)-c\right)>P(L)$, where $x$ is an integer 2 or greater and $c$ is the cost per lot of subdivision.

5. No reasoning about total lot supply is necessary to explain the existence of a gap between marginal and average prices.

6. Tax incidence is always on the landowner.

7. Minimum lots sizes increase average compared to marginal prices at a location.

Even though this Inverted-U model suggests there are sub-optimality large lot sizes when marginal land prices are below the average, it also cannot be used to reason about the effect on planning controls. It makes no assumptions about the existence of a static equilibrium housing stock, nor about the rate of new housing supply per period. Instead, it simply shows that a classical model of scarce locations is consistent with a gap between marginal and average lot prices if subdivisions occur over time and location values change, and is also consistent with the subdivision behaviour necessary for new lot supply.

\section{G\&G's method with a known data generation process}

Apart from location values, what does G\&G's method actually identify? To answer that question we create simulated suburbs using known data-generating processes to see how their method differentiates them.

It is important in this exercise to simulate a process of development over time, as at any point in time a city or suburb will comprise plots of land that were subdivided during different historical 
periods under different economic conditions. Unless every piece of land is continuously amalgamated and re-subdivided to ensure that optimally-sized lots at all locations across the city there will be a variety of non-optimally sized plots of land. ${ }^{9}$

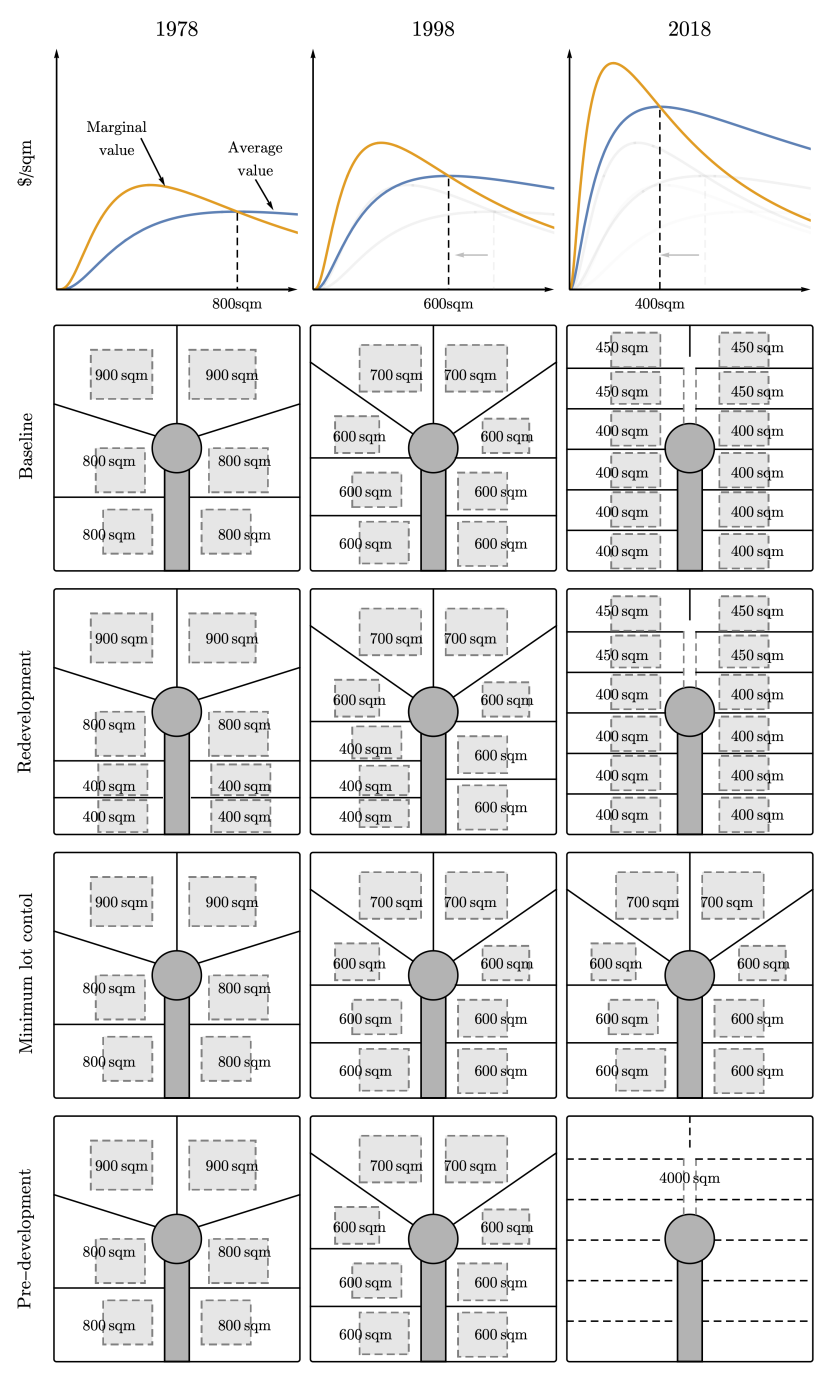

Figure 4: Suburb development patterns with different data-generating processes

Figure 4 visualises the Baseline and other scenarios for these simulations. The top row shows how the marginal and average utility (bid-rent) curves change for this suburb at three points in time; 1978, 1998, and 2018. The suburb comprises three large 4,000 square metre englobo blocks of neighbouring land, with one plot subdivided into nearly-optimally-sized detached residential housing lots in each model year - in 1978 the left block is subdivided, in 1998 the centre block is subdivided, and in 2018 the right block is subdivided. So when observing the suburb in 2018 all three large blocks have been subdivided into lot housing, where the pattern of lot sizes reflects

\footnotetext{
${ }^{9}$ This critique has been raised before - as Somerville (2005) noted, the "standard urban model upon which the specification rests essentially is a city without durability. As land prices change, houses are instantly remade" - but a clear elucidation will show it to be a key driver of the empirical results.
} 
the historical timing of each subdivision. The scenarios here do not imply any particular dynamic incentives regarding the choice of timing for each of the three subdivisions in the suburb, only that they did occur over this historical period for economic reasons that made sense at the time.

The Baseline row of Figure 4 shows what these nearly-optimally-sized subdivisions look like, with lot and house outlines marked. It is almost never possible to subdivide the englobo block into multiples of the optimal lot size, which occurs when marginal and average value is equal. Each subdivision also faces the suitcase problem of geographic and accessibility constraints, such as driveway access to the cul de sac, which must also be optimised with respect to buyer utility for lot shape and depth. In 1978 and 1998 this means that lots with limited frontage in the cul-de-sac are larger to minimise land devoted to roads while maximising the total land value. We show here that in 2018 road access can be addressed more effectively by an easement from the cul-de-sac (shown in dashed lines), but this reduces the value of those lots without direct road access, and hence those lots are slightly larger to maximise overall land value of the subdivision. These type of suitcase problems will be far more pronounced in reality than in this simple demonstration.

The four scenarios studied here are outlined below, with the patterns of housing lots in each represented by a row of Figure 4.

1. Baseline: There are no planning constraints and nearly-optimal subdivision occurs for one block at each of the three time periods but none of the housing lots are subsequently redeveloped.

2. Redevelopment: As per Baseline, but some previously subdivided lots that meet the criteria $x\left(P\left(\frac{L}{x}\right)-c\right)>P(L)$ have been re-subdivided to increase the total number of lots by $12 \%$.

3. Minimum lot size: As per Baseline, but a minimum lot size control of 600 square metres binds the when the final subdivision occurs.

4. Pre-development: As per Baseline, but the analysis occurs immediately prior to the subdivision of the third block in 2018, so it includes only the historically subdivided lots. The important feature of this scenario is that there are no regulatory constraints, and the number of housing lots in the suburbs is about to increase more than $85 \%$.

For all scenarios we assume that lots are supplied perfectly elastically over time. This implies that the population, or number of desired households, is proportional to the number of housing lots in each scenario. In the Minimum lot size scenario we assume that the rate of new housing supply is unaffected by this planning control (implying that there are other neighbouring blocks able to be subdivided to meet any future demand changes even in 2018).

Prices for lots in 2018 (land price only, excluding house costs) are determined by the Inverted-U model, with the total utility (bid-rent) function specified in Equation 1 as a modified form of a log-normal cumulative density function (CDF)

$$
U_{L}=l o c^{2} c \operatorname{Erfc}\left(\frac{1-l o c \ln [a L]}{\sqrt{2} l o c^{2}}\right)
$$

where $l o c$ represents the relative location value, and scales the function by $l o c^{2}$ while modifying its shape due to $\frac{1}{l o c}$ substituting for $\mu$ and loc substituting for $\sigma$ from the standard log-normal CDF. $L$ is the lot size in square metres, and $c$ and $a$ are adjustment factors to map the function 
Table 1: Lot prices, quantities, and means, for simulation scenarios (2018 prices)

\begin{tabular}{|c|c|c|c|c|c|c|c|}
\hline \multirow[b]{2}{*}{$\begin{array}{l}\text { Lot size } \\
\left(\mathrm{m}^{2}\right)\end{array}$} & \multicolumn{3}{|c|}{2018 prices } & \multicolumn{4}{|c|}{ Number of lots of each size } \\
\hline & $\begin{array}{r}\text { Total } \\
(\$ ’ 000)\end{array}$ & $\begin{array}{c}\text { Average } \\
\left(\$ / \mathrm{m}^{2}\right)\end{array}$ & $\begin{array}{l}\text { Marginal } \\
\left(\$ / \mathrm{m}^{2}\right)\end{array}$ & Baseline & $\begin{array}{r}\text { Redevel- } \\
\text { opment }\end{array}$ & $\begin{array}{r}\text { Min. lot } \\
\text { size }\end{array}$ & $\begin{array}{r}\text { Re-devel- } \\
\text { opment }\end{array}$ \\
\hline 900 & 74.7 & 83 & 47 & 2 & 2 & 2 & 2 \\
\hline 800 & 69.6 & 87 & 54 & 4 & 2 & 4 & 4 \\
\hline 700 & 63.8 & 91 & 63 & 2 & 2 & 4 & 2 \\
\hline 600 & 57.0 & 95 & 73 & 6 & 4 & 12 & 6 \\
\hline 450 & 44.6 & 99 & 92 & 4 & 4 & 0 & 0 \\
\hline 400 & 39.8 & 100 & 100 & 8 & 15 & 0 & 0 \\
\hline \multicolumn{4}{|c|}{ Total lots } & 26 & 29 & 22 & 14 \\
\hline \multicolumn{4}{|c|}{ Mean lot price $\left(\${ }^{\prime} 000\right)$} & 53.6 & 49.0 & 62.1 & 64.1 \\
\hline \multicolumn{4}{|c|}{ Mean lot size (sqm) } & 577 & 517 & 682 & 714 \\
\hline \multicolumn{4}{|c|}{ Mean land price/sqm } & 93.0 & 94.7 & 91.1 & 89.8 \\
\hline \multicolumn{4}{|c|}{ Average age of lot (yrs) } & 15.4 & 9.7 & 18.2 & 28.6 \\
\hline
\end{tabular}

to realistic price and land sizes in dollars and square metres. ${ }^{10}$ The prices in 2018 for each lot based on this total utility (bid-rent) function are summarised in Table 1, alongside a summary of the distribution of lot sizes in each scenario, and the resulting mean prices, lot sizes, and prices per square metre.

G\&G's method is replicated on the data in each scenario by estimating price elasticities with respect to land area using the log-transformed price and size of each $i$ lot as per Equation 2 .

$$
\log P_{i}=\alpha+\beta \log L_{i}+\epsilon
$$

The estimate of $\beta$ is an elasticity and is converted into an estimate of $p$ by multiplying it by the mean price per square metre in the sample. An estimate of $T$ is then calculated by subtracting this estimate of $p$ from the mean price per square metre and multiplying by the mean lot size.

There are some important patterns in these results. First, although the rate of new housing is unconstrained and elastically supplied, the estimate of $T$ is more than $20 \%$ of the lot price in all scenarios.

Second, although the Redevelopment scenario has a substantial investment of three new dwellings at the optimal size (12\% more dwellings than the Baseline) there is only a small $3 \%$ effect on the size of $T$ as a share of total land price. Importantly, because there are more lots close to the optimum size the estimate of $p$ has also increased, from $\$ 74.3$ to $\$ 76.3$. This suggests that the measurement of $p$ is not a "free market price" of land that can be obtained independently of the size distribution of current lots, but rather is itself strongly determined by the existing densities and patterns of development. If that is the case, then the idea that land lots can be assembled

\footnotetext{
${ }^{10}$ In this instance, $l o c=1.10, c=50,000$ and $a=\frac{3}{800}$, which produces average and marginal utility curves as per the 2018 graph in the top row of Figure 4. For the 1978 and 1998 graphs in Figure 4, loc is 0.85 and 0.96 respectively. The parameters were chosen to provide clean round-number results for optimal lot sizes in each time period. The marginal utility curve is the probability density function (PDF) of the log-normal distribution with the same location scaling and parameter substitutions.
} 
Table 2: Replication results for scenarios with known data-generating processes

\begin{tabular}{lrrrr}
\hline \hline & Baseline & $\begin{array}{r}\text { Redevel- } \\
\text { opment }\end{array}$ & $\begin{array}{r}\text { Min. lot } \\
\text { size }\end{array}$ & $\begin{array}{r}\text { Pre-devel- } \\
\text { opment }\end{array}$ \\
\hline $\begin{array}{l}\text { Regression results } \\
\text { Land area }(\mathrm{ln})\end{array}$ & 0.80 & 0.81 & 0.68 & 0.68 \\
\hline "Regulatory tax" analysis & & & & \\
Average land price $\left(\$ / \mathrm{m}^{2}\right)$ & 93.0 & 94.7 & 91.1 & 89.8 \\
Marginal land price, $p\left(\$ / \mathrm{m}^{2}\right)$ & 74.3 & 76.3 & 62.2 & 60.9 \\
$T(\$$ '000) & 10.8 & 9.5 & 19.7 & 20.6 \\
$T$ share of $L(\%)$ & 20.0 & 19.4 & 31.7 & 32.1 \\
\hline \hline
\end{tabular}

All coefficient estimates are significant $(p<0.01)$, as expected with a hypothetical error-free scenario, and the model $\mathrm{R}$ squared rounds to one is all cases.

at the per square metre price of $p$ in the absence of planning controls is wrong. It is hence also incorrect to state that "[e]ven in communities where new houses are not being built, the hedonic value of land still gives us an implicit price of land" (Glaeser \& Gyourko, 2003, p. 28).

Third, the Minimum lot size scenario has a higher estimate of $T$, perhaps indicating there is some value to G\&G's method for detecting planning controls. But here it is explicitly the case that the minimum lot control has not restricted the rate of new housing supply. It also worth noting that the higher estimate of $T$ in this scenario only occurs if the data is generated as per the Inverted-U model. If the data is generated as per G\&G's model, this scenario will have a lower estimate of $T$ compared to the Baseline unless additional assumptions are made about how minimum lot size regulations increase relative location values (as described in Section 2.1.5).

Fourth, the Pre-development scenario is unconstrained and is in the process of rapid development, yet here $T$ accounts for $32 \%$ of the land price, which is higher than in the Minimum lot size scenario. G\&G's method is unable to differentiate between patterns of development generated by minimum lot size regulations, and the presence of many future development options in a suburb experiencing a high rate of new housing supply.

Another pattern that stands out is that the rank order of scenarios by their estimated $T$ share of land price is the same as their rank by average lot age. To tease this out further we applied G\&G's empirical method to the Baseline scenario in the 1978 and 1998 time periods of the simulation ${ }^{11}$, and found that in those time periods that $T$ was $5 \%$ and $13 \%$ of the total land price, while the average lot age was zero and 8.6 years respectively, confirming the relationship between lot age and estimated $T$. That G\&G's method indirectly measures the age of housing lots was a critique made by O'Flaherty (2003) and discussed in Section 2.1.1.

Applying G\&G's method to simulated data has demonstrated that it identifies numerous patterns of unconstrained housing development as being due to high costs of land regulation, particular with older housing lots, and that the "free market price" of land, $p$, that it estimates, is in fact highly dependent on the current distribution of lot sizes.

\footnotetext{
${ }^{11}$ Using prices generated from the utility (bid-rent) function from each period as per Equation 1 with loc values of 0.85 in 1978 and 0.96 in 1998.
} 


\section{Historical cases: Colonial Australia and Mesopotamia}

A final check of whether G\&G's method detects the price effects of planning constraints is to apply it to data that is highly unlikely to be affected by modern planning controls. Two cases are used. First, is colonial Australia in the 1850s in the state of Queensland using land sales data of homesteads that are located in what are now suburbs of Brisbane. The population of Queensland in this period was around 17,000 people and these sales were the first sales to the private sector of newly subdivided land held by a government that was eager to foster development. ${ }^{12}$ What is most interesting in this land data is that many subdivisions contained only lots of equal size, implying that there were few geographic constraints for many subdivisions. But as discussed in Section 2.1.1, when this occurs it limits the ability to measure marginal land values. As such, three subdivisions with a degree of lot size variation from December 1851 to June 1854 are used for this analysis. The principle point here is that the variation of land size in these new subdivision samples cannot be due to town planning constraints, and must be from other constraints such as geography and accessibility.

The second case is ancient Mesopotamia, the location of modern Iraq, in the third millennium B.C. Records of land sales from clay tablets that match kudurrus, or 'boundary stones', are the conceptual origins of modern private land registers. and sales records from this period have been translated and summarised by Gelb et al. (1991). Even though this case seems far removed from the housing supply and planning issues of modern cities, what makes it relevant to this critique is that location values were even in ancient times a key factor breaking down the otherwise linear relationship between land size and price (i.e. when marginal equals average price). Indeed, it was a feature of the data that historians felt was necessary to highlight.

An exception to the formula is found in the case of a small plot of exceptionally productive land... This distortion of the linear increase in price with increasing productivity is not surprising. The labor saved in working a small field with a high yield would compensate for a premium in price over the expected rate. (Gelb et al. , 1991, p. 283)

Table 3 shows the results of these model estimations (as per Equation 2) and subsequent "regulatory tax" analysis, with the Mesopotamian records analysed separately on the basis of the type of land sold (houses, fields, and other land). In all cases the data shows a "regulatory tax", with $T$ comprising $34 \%$ of the land price for fields and $16 \%$ of the price for Other land types. While the coefficient estimate for land size for houses in Mesopotamia was not significant $(p=0.32)$, perhaps due to the inability to add further hedonic controls, the size and direction of the estimate at 0.22 is consistent with the story so far that lower marginal compared to average land prices are due to the shape of the demand curve regardless of the data-generating process on the supply size. Only if the land component of the house price was less than $22 \%$ of total house cost would there be no "regulatory tax" in this instance.

It is certainly the case that there may be unobserved restrictions on lot development in these cases. But they add further evidence against the strong interpretation of G\&G that their method measures the price effect of planning controls.

\footnotetext{
${ }^{12}$ Data was manually transcribed from microfilm records at the Queensland State Archives and is available at https://www.fresheconomicthinking.com/p/works.html.
} 
Table 3: Replication results for historical cases

\begin{tabular}{|c|c|c|c|c|c|c|}
\hline & \multirow{2}{*}{\multicolumn{2}{|c|}{$\begin{array}{c}\text { Colonial Australia } \\
\text { (units) }\end{array}$}} & \multicolumn{4}{|c|}{ Ancient Mesopotamia } \\
\hline & & & Houses & Fields & Other & (units) \\
\hline \multicolumn{7}{|l|}{ Data description } \\
\hline Mean lot price & 22.6 & $(£)$ & 11.6 & 22.6 & 385.2 & (gin) \\
\hline Mean lot size & 12.2 & $\left(1,000 \mathrm{~m}^{2}\right)$ & 2.3 & 67.4 & 147.4 & $(\mathrm{iku})$ \\
\hline \multicolumn{7}{|l|}{ Regression results } \\
\hline Land area $(\ln )$ & $0.54^{* * *}$ & & 0.22 & $0.66^{* * *}$ & $0.84^{* * *}$ & \\
\hline Controls & Yes & & Yes & Yes & Yes & \\
\hline $\mathrm{R}^{2}$ & 0.61 & & 0.06 & 0.52 & 0.94 & \\
\hline $\mathrm{N}$ (number of lots) & 68 & & 34 & 69 & 114 & \\
\hline \multicolumn{7}{|l|}{ 'Regulatory tax' analysis } \\
\hline Average land price & 1.9 & $\left(£ / 1,000 \mathrm{~m}^{2}\right)$ & 5.0 & 0.3 & 2.6 & $(\mathrm{gin} / \mathrm{iku})$ \\
\hline Marginal land price, $p$ & 1.0 & $\left(£ / 1,000 \mathrm{~m}^{2}\right)$ & 1.1 & 0.2 & 2.2 & $(\mathrm{gin} / \mathrm{iku})$ \\
\hline$T$ & 10.4 & $(£)$ & 9.0 & 7.7 & 61.6 & $(\operatorname{gin})$ \\
\hline
\end{tabular}

Suburb location controls in Colonial Australia regression, control for orchards in Fields regression, control for currency type in Houses, and controls for sources of land sale records in Other regression (e.g. Nippur Stone, Baltimore Stone, Adab Stone Fragment, etc.). One $i k u$ is 0.35 Ha. Land area for Houses are measured in sar, which is approximately one-hundredth of an $i k u$.

\section{Discussion and conclusions}

While a lower marginal compared to average land price for housing lots has broadly been thought to be an indicator of the economic cost of planning constraints or development taxes, in reality, this measure contains no information about the effect of planning controls. Indeed, the popularity of the G\&G method is somewhat surprising given it was initially published alongside a critique that came to this exact conclusion.

Regardless of this academic history, housing policy-makers globally have been receptive to conclusions based on G\&G's method and many have identified planning policies as the major determinant of land prices. Such a belief is likely to create a bias toward policies that sacrifice the amenity benefits of planning controls in order to pursue illusory home price benefits. There is thus a need for a more robust critique that can shift the academic debate and reach policy-makers.

To avoid repeating the many additional critiques covered here, a summary of them is in Table A2. Each on its own should be sufficient to caution against relying on the method to inform key policy decisions, but together they make that case that the method of comparing marginal and average residential land prices is not a valid way to determine the housing price effect of planning regulations.

There are two remaining issues worth discussing regarding the direction of research in this area. One is the political economy of the debate. The greatest calls to remove planning constraints usually come from housing developers themselves. If removing constraints did radically reduce land prices, then housing developers are undermining their own profitability by calling for more relaxed planning controls. They should instead be lobbying for tighter planning controls. This 
alone should raise questions about the mechanism by which price effects from planning regulations occur.

Table 4: Implied economic power of the planning profession

\begin{tabular}{lrrr}
\hline \hline City & $\begin{array}{r}\text { Share of residential land } \\
\text { value due to planning }\end{array}$ & $\begin{array}{r}\text { Total residential } \\
\text { land value } \\
(\$ \text { billion })\end{array}$ & $\begin{array}{r}\text { Planning } \\
\text { effect } \\
(\$ \text { billion })\end{array}$ \\
\hline Detroit & 0.91 & 219 & 200 \\
Houston & 0.63 & 213 & 134 \\
Kansas City & 0.14 & 78 & 11 \\
Los Angeles & 0.91 & 1,003 & 917 \\
Philadelphia & 0.76 & 423 & 321 \\
Phoenix & 0.73 & 306 & 223 \\
Pittsburgh & 0.44 & 92 & 41 \\
Riverside & 0.80 & 247 & 197 \\
San Francisco & 0.88 & 256 & 225 \\
\hline Total & 0.80 & 2,837 & 2,269 \\
\hline \hline
\end{tabular}

Share of land value due to planning is from Glaeser \& Gyourko (2003) for cities where their model regression has a significant coefficient for $\ln (L)$, and urban land values are 2010 estimates from Albouy et al. (2017).

The similar results for Detroit and San Francisco are interesting. Detroit is experiencing a long-term population decline and has an average land value of $\$ 5.10$ per square foot. San Francisco is high-demand location experiencing high population growth with an average land value of $\$ 63.72$ per square foot. Yet in both cases town planning is claimed to be the cause of around $90 \%$ of residential land values.

The other remaining issue concerns the economic power of town planners implied by G\&G and their method. For example, Glaeser \& Gyourko (2003) found that 91\% of the residential land value in Los Angeles was due to planning constraints. In 2010 the total value of residential land in Los Angeles was estimated to be $\$ 1$ trillion, implying that over $\$ 900$ billion of that land value was caused by planning controls. In Table 4, the share of land value attributed to planning controls has been summarised for the nine cities where G\&G found significant effects. For these cities, $80 \%$ of residential land value is attributed to planning controls. Matching these estimates to estimates of the total value of residential land in these cities in 2010 from Albouy et al. (2017), leads to the conclusion that $\$ 2.3$ trillion of residential land value in these cities alone was created by town planning rules. Removing planning constraints in these cities could rapidly wipe $\$ 2.3$ trillion in land value from the balance sheets of homeowners in these cities - a shock to household balance sheets similar to the late 2000s financial crisis, where home prices (house and land) fell $31 \%$ nationally according to the Case-Schiller Index. This seems implausible.

Though the G\&G method lacks merit, we should not discount the idea that planning controls may have significant effects on land prices and their distribution. But overly large estimates of the effect on house prices of town planning regulations are an unnecessary distraction when it comes to improving planning regulations to increase welfare. To contribute constructively to the evidence base requires focussing on development timing decisions and the subsequent rate of supply of new housing, as well as the locational distribution of new housing. 


\section{References}

Albouy, David, Ehrlich, Gabriel, \& Shin, Minchul. 2017. Metropolitan land values. Review of Economics and Statistics, 100(3), 454-466.

Gelb, Ignace J, Steinkeller, Piotr, \& Whiting, Robert M. 1991. Earliest land tenure systems in the Near East-ancient kudurrus. Oriental Inst. of the University of Chicago.

Girouard, Nathalie, Kennedy, Mike, van den Noord, Paul, \& André, Christophe. 2006. Recent House Price Developments.

Glaeser, Edward, \& Gyourko, Joseph. 2002. Zoning's steep price. Regulation, 25, 24.

Glaeser, Edward L., \& Gyourko, Joseph. 2003. The Impact of Building Restrictions on Housing Affordability. Federal Reserve Bank of New York Policy Review, 9(2), 21-39.

Glaeser, Edward L, Gyourko, Joseph, \& Saks, Raven. 2005. Why is Manhattan so expensive? Regulation and the rise in housing prices. The Journal of Law and Economics, 48(2), 331-369.

Hilber, Christian AL, \& Vermeulen, Wouter. 2015. The impact of supply constraints on house prices in England. The Economic Journal, 126(591), 358-405.

Kendall, Ross, \& Tulip, Peter. 2018. The Effect of Zoning on Housing Prices. Research Discussion Paper 2018-03. Reserve Bank of Australia.

LEes, Kirdan. 2018. Quantifying the costs of land use regulation: evidence from New Zealand. New Zealand Economic Papers, May, 1-25.

MacDonald, Graham. 2016. The Effect of Local Government Policies on Housing Supply. Terner Center for Housing Innovation at UC Berkeley.

Markusen, James R, \& Scheffman, David T. 1978. The timing of residential land development: A general equilibrium approach. Journal of Urban Economics, 5(4), 411-424.

Murray, Cameron K. 2018. Developers pay developer charges. Cities, 74, 1-6.

Niemietz, Kristian. 2012. Abundance of land, shortage of housing. IEA discussion.

O'Flaherty, Brendan. 2003. Commentary (on Glaeser and Gyourko). Federal Reserve Bank of New York Policy Review, 9(2), 41-43.

Shoup, Donald C. 1970. The optimal timing of urban land development. Papers in Regional Science, 25(1), 33-44.

Somerville, C Tsuriel. 2005. Zoning and Affordable Housing: A Critical Review of Glaeser and Gyourko's Paper. Canada Mortgage and Housing Corporation.

Sunding, David, \& Swoboda, Aaron M. 2009. Rationing in the Market for New Housing. University of California, Department of Agricultural and Resource Economics.

Titman, Sheridan. 1985. Urban land prices under uncertainty. The American Economic Review, 75(3), 505-514.

WALras, LÉOn. 2010. Studies in social economics. Routledge. 


\section{Appendix}

Table A1: Theoretical structure of G\&G model and Inverted-U model compared

\begin{tabular}{|c|c|c|}
\hline & Glaeser \& Gyourko (G\&G) & Inverted-U \\
\hline $\begin{array}{l}\text { Utility function* } \\
\text { where }\end{array}$ & $\begin{array}{l}U_{l o c}(L)=l o c+L^{\alpha}-P_{l o c}(L) \\
l o c=\text { location-specific amenity } \\
L=\text { land size } \\
P=\text { lot price at location } \\
0<\alpha<1\end{array}$ & $\begin{array}{l}U_{l o c}(L)=V(l o c, L)-P_{l o c}(L) \\
V^{\prime}(l o c)>0 \\
V^{\prime}(L)>0 \\
V^{\prime \prime}(L)>0 \leftrightarrow L<x \\
x=L^{*} \text { when } V(L) / L=V^{\prime}(L)\end{array}$ \\
\hline $\begin{array}{l}\text { Conditions for utility } \\
\text { maximisation }\end{array}$ & $\begin{array}{l}U^{\prime}\left(L^{*}\right)=p \\
U^{\prime \prime}\left(L^{*}\right)<0\end{array}$ & $\begin{array}{l}U^{\prime}\left(L^{*}\right)=P^{\prime}\left(L^{*}\right) \\
U^{\prime \prime}\left(L^{*}\right) \leq 0\end{array}$ \\
\hline $\begin{array}{l}\text { Total cost of land } \\
\text { where }\end{array}$ & $\begin{array}{l}P_{l o c}=T+p L \\
T=\text { regulatory tax } \\
p=\text { marginal price of } \mathrm{L}\end{array}$ & $P_{l o c}=U_{l o c}(L)$ \\
\hline $\begin{array}{l}\text { Conditions for } \\
\text { subdivision } \\
\text { revenue maximisation }\end{array}$ & $\begin{array}{l}\text { Tax }(\text { or } T=0) \\
R(L)=p L / L \\
R^{\prime}(L)=0 \\
\text { Quantity limit (i.e. } T>0) \\
R(L)=(T+p L) / L \\
R^{\prime}(L)=-T L^{-2}\end{array}$ & $\begin{array}{l}\text { Since } R(L)=P_{l o c} / L \\
R^{\prime}(L)=P_{l o c}^{\prime}(L)-P_{l o c}(L) / L \\
R^{\prime}(L)=0 \text { if } \\
P_{l o c}^{\prime}(L)=P_{l o c}(L) / L\end{array}$ \\
\hline Subdivision incentive & $\begin{array}{l}\text { Either none, or for } \\
\text { land size of zero only. }\end{array}$ & $\begin{array}{l}\text { If } x\left(P\left(\frac{L}{x}\right)-c\right)>P(L) \\
\text { where } x \text { is an integer } 2 \text { or greater } \\
\text { and } c \text { is the per-lot subdivision cost }\end{array}$ \\
\hline $\begin{array}{l}\text { Equilibrium } \\
\text { conditions }\end{array}$ & $\begin{array}{l}U^{\prime}\left(L^{*}\right)=p \\
\frac{\partial U}{\partial l o c}=\frac{\partial P}{\partial T}\end{array}$ & $\begin{array}{l}U^{\prime}\left(L^{*}\right)=P^{\prime}\left(L^{*}\right)=P\left(L^{*}\right) / L^{*} . \\
\frac{\partial U}{\partial l o c}=\frac{\partial P}{\partial l o c}\end{array}$ \\
\hline
\end{tabular}

* While G\&G do not assume a linear relationship between utility and location, there appears no logical way to differentiate their "location-specific amenity" and the "utility from location-specific amenity". They must be the same thing so here for simplicity $l o c$ enters their utility function as a scalar. 
Table A2: Summary of critiques of G\&G's method and theoretical basis

\begin{tabular}{ll}
\hline \hline Section & Arguments \\
\hline 1 & Land is not a quantity. \\
& The suitcase problem limits optimal subdivision. \\
& Optimal subdivision can only be temporary. \\
\hline 2.1 .1 & $\begin{array}{l}\text { If all lots are optimally sized then marginal prices cannot be empirically estimated. } \\
\text { Land development timing choices are independent of allowed development density. }\end{array}$ \\
\hline 2.1 .2 & The "regulatory tax" is merely the location value. \\
\hline 2.1 .3 & $\begin{array}{l}\text { It is inconsistent to argue that housing lots are scarce but marginal land for those } \\
\text { same lots is not. }\end{array}$ \\
\hline 2.1 .4 & $\begin{array}{l}\text { G\&G's theory of land prices has no incentive for subdivision (new lot production). } \\
\text { There is no optimal lot size. }\end{array}$ \\
\hline 2.1 .5 & $\begin{array}{l}\text { The economic incidence of taxes on new housing matters. } \\
\text { Inconsistent reasoning about land supply per lot and total lot supply . } \\
\text { Minimum lot sizes might reduce the "regulatory tax". }\end{array}$ \\
\hline 3 & $\begin{array}{l}\text { A price-taking Inverted-U model has more reasonable assumptions, is } \\
\text { internally consistent, predicts subdivision, and matches the data. }\end{array}$ \\
& $\begin{array}{l}\text { A high "regulatory tax" is estimated on simulated unconstrained land data. } \\
\text { The method cannot detect the difference between an area with minimum lot sizes } \\
\text { and an area with no lot size constraints undergoing rapid development. }\end{array}$ \\
\hline \hline & $\begin{array}{l}\text { The G\&G method detects large "regulatory taxes" in historical situations where } \\
\text { planning constraints are unlikely to be a factor. }\end{array}$ \\
\hline
\end{tabular}

